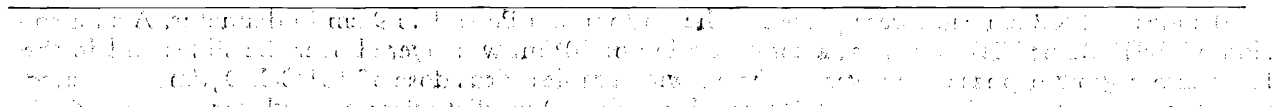

\section{KINETICS OF RABIES VIRUS REPLICATION IN CELL CULTURES}

\author{
V. CELER, G. BELAY and V. CELER, Jr.
}

Department of Microbiology and Immunology, University of Veterinary Science, 61242 Brno

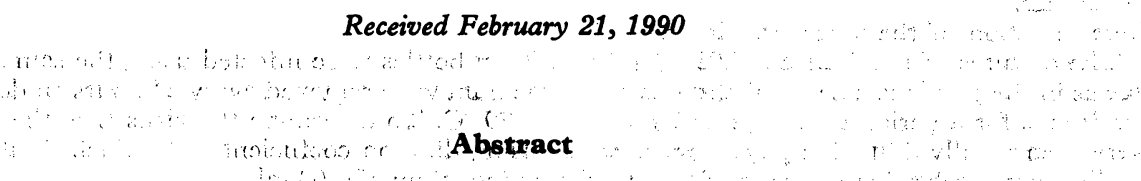

Celer V., G. Belay, V. Celer, Jr.: Kinetics of Rabies Virus Replication in Cell Cultures. Acta vet. Brno, 60, 1991: 161-164.

While studying the kinetics of rabies virus replication in course of its adaptation to the cell culture (CC) of the lines BHK-21 and VERO, we detected the first fluorescing 'loci in $1 \%$ of the cells $6-8$ hours after infection and in $100 \%$ of the cells 24 hours after infection. With an input multiplicity of 10 per cell, the maximum titre of extracellular virus was detected in the cell culture on day 5 when it reached a value of $10^{7,2} \mathrm{CCID}_{50} / \mathrm{ml}$ in slide cultures, and that of $10^{5,4} \mathrm{LD}_{50} / 0.03 \mathrm{~cm}^{3}$ for mice aged 3-5 days.

Rabies virus, tissue culture, kinetics of replication

Until recently, vaccine against rabies was based on brain tissue preparation which often caused serious anaphylactic reactions in humans. New possibilities have become available after a successful adaptation of rabies virus to tissue culture conditions. However, this adaptation has still been associated with serious problems resulting from the latent nature of the infection and its slow development both in the nerve tissue of infected animals as well as in the cultures.

$K i s s l i n g$ (1958) wa the first to propagate rabies virus in tissue culture. Cultivation of a fixed strain and CVS strain of the virus in a CC of hamster kidneys was first described by Kaplan and coworkers in 1960.' Further reports of a successful replication of both fixed and street strains of the virus in CC of various origins were becóming more numerous (Abelseth 1964, Hronovský et. al. 1966, and others). In the course of these adaptations the main features that were followed included changes in pathogenic properties for laboratory animals $(R \mathbf{u l k a}$ et. al. 1974), the occurrence of a cytopathic effect (CPE), neural pathogenicity (Hronovský et. al. 1968), and the effects of rabies infection on the host cell. Great attention is also paid to production of large quantities of the virus for the purpose of both human and veterinary use.

This study was aimed at the kinetics of the replication of a street strain of rabies virus of local provenience in the course of its adaptation to CC, and at determination of the optimal harvest time for subsequent vaccine preparation.

\section{Materials and Methods}

Virus: a street strain "Príbram" of rabies virus was used in the course of its adaptation to the BHK-21 and VERO cell lines in passage No. 36. The virus was maintained at $-79^{\circ} \mathrm{C}$.

Cells: cell line BHK-21 was grown in MEM medium supplement with $2-10 \%$ fetal calf serum (FCS), gluta mine, and non-essential amino acids. The VERO cell line was obtained from the Tissue Culture Department of VÚVeL, Brno, and was grown in M-199 medium containing 2-10\% FCS, glutamine and non-essential amino acids. The cells were cultivated in $500 \mathrm{ml}$ Roux bottles, or on slides in Petri dishes in an atmosphere of $5 \% \mathrm{CO}_{2}$.

Mice: white laboratory mice aged 3-5 days were used for the titration of the virus. 
Kinetics of virus replication

10 slides of $1 \times 2 \mathrm{~cm}$ each were placed at the bottom of a Petri dish $9 \mathrm{~cm}$ in diameter. A su spension of BHK-21 or VERO cells at a concentration of $10^{5} / \mathrm{ml}$ was layered over the slides and in the logarithmic growth phase they were infected with a rabies virus dose of $10^{8} \mathrm{CCID}_{50} / \mathrm{ml}$.In fection with the virus was performed in MEM medium with $50 \mu \mathrm{g}$ diethylaminoethyl-dextran $/ \mathrm{ml}$ which was followed by a subsequent incubation for $90 \mathrm{~min}$. at $32{ }^{\circ} \mathrm{C}$. After this period the cell s were washed $2 \times$ with MEM medium without the serum and then incubated in maintaining medium with $2 \% \mathrm{FCS}$ at $32{ }^{\circ} \mathrm{C}$. In the following 24 hours 2 slides were removed every 2 hours, and then every 6 hours for a period of 5-6 days. The cells were fixed with acetone cooled to $-20^{\circ} \mathrm{C}$ for 20 minutes. Antirabies conjugate (FITC) wes used to label the fixed cells according to the method of Dean and Abelseth (1974) and the preparations were evaluated using the fluorescence microscope Jenalumar.

Determination of the virus titre in the cell culture

The cultures of BHK-21 and VERO cells in Roux bottles were infected using the same technique as in the previous case. $2 \mathrm{ml}$ aliquots of the medium were removed every 24 hours under sterile conditions for a period of 6 days and stored at $-79^{\circ} \mathrm{C}$. To determine the virus titre the samples were then serially diluted in physiological saline using dilution coefficient of 10 . Each dilution was applied intracerebrally to a group of 5 mice with an inoculum of $0,03 \mathrm{ml}$.

Analogously, but with a dose of $0.1 \mathrm{ml}$, the virus was titrated in CC always on 3 slides.

The virus titre was calculated according to Reed and $M$ ünch (1938). The brains of dead mice were examined with direct fluorescence (Dean and Abelseth 1974). The antirabies conjugate was obtained from Bioveta, n. p., Ivanovice na Hané, diluted 1:20 and stained with Evans Blue at a dilution of $1: 2000$. The preparations were evaluated with the fluorescent microscope Jenalu mar.

\section{Results}

\section{Kinetic studies of the virus replication in CC}

The first specific fluorescence was repeatedly detected 6 hours after infection in BHK-21 ceifie and 8 hours after infection in VERO cells. The first fluorescing bodies were rather minute and they were in approximately $1 \%$ of the cells. The number of the infected cells was increasing to $30-40 \% 10-12$ hours after infection, and the number of the minute fluorescing bodies increased markedly within the cells filling the whole of the cytoplasm and fusing to form flat bodies at the cell periphery. Not until 24 hours after infection the number of the infected cells reached $100 \%$ (Figs. 1, 2, Plate XVII; Figs. 3, 4).

At the same time, the nature of the fluorescing bodies was changing so as to surround the cells in form of a fine veil, and they became most conspicuous in the intercellular spaces.

\section{Titration of the virus}

The results of the virus titration in CC in 24-hour intervals are shown in Fig. 2. It is evident that as early as 24 hours after infection the titre of the virus reached relatively a high value, i. e. $10^{3,5} \mathrm{CCID}_{50} / 1 \mathrm{ml}$. The maximum titre of $10^{7,2} \mathrm{CCID}_{50} / 1 \mathrm{ml}$ was detected on day 5 following the infection. Similar results were obtained when titrating the virus in mice as shown in Fig. $5\left(10^{3,0} \mathrm{MLD}_{50} / 0.03\right.$ $\mathrm{ml}$ on day 2 , and $10^{5,54} \mathrm{MLD}_{50} / 0,03 \mathrm{ml}$ on day 5 ).

\section{Discussion}

Although a number of authors have investigated inclusions specifically fluorescing in CC after infection with rabies virus (e. g. Wiktor 1966), we studied the virus of lyssa isolated from the brain tissue of the common fox from the 
Príbram region in course of its adaptation to CC. Our results correspond to those of Wiktor (1966). The two-phase growth curve for the number of the infected cells corresponded to the 2 cycles of virus replication. We also recorded a change of the large fluorescing bodies present in the brain tissue of the fox or in the initial passages of the virus in CC towards very fine, dust-size bodies in passage No. 36 .

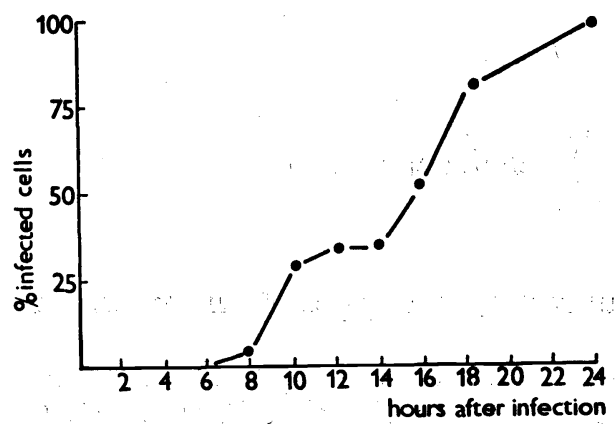

Fig. 3. Per cent of infected cells

The maximal titre of the virus was recorded on day 5 after infection. The results resemble those of Rifky and E1-Karamany (1987). Other authors, as Fenje (1960) reported the optimal time for harvesting the virus as $10-14$ days following the infection. However, this difference can be explained by the degree

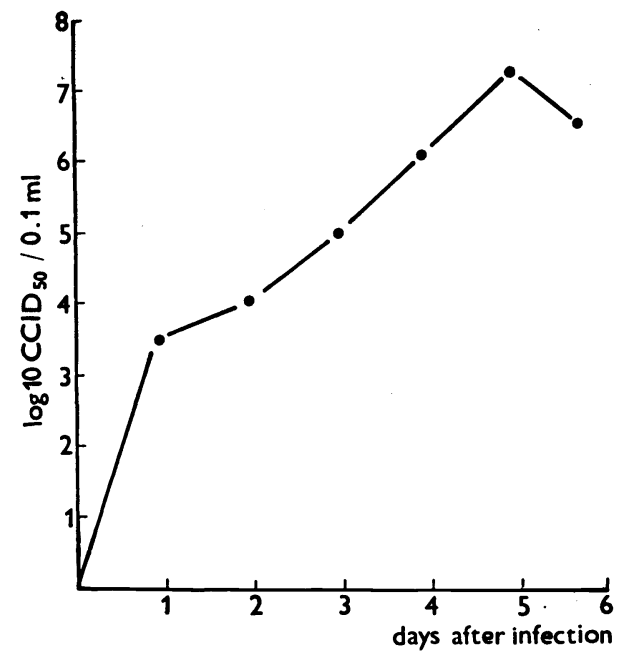

Fig. 4. Titre of extracellular virus in cell culture

Fig. 5. Titration of extracellular virus in mice

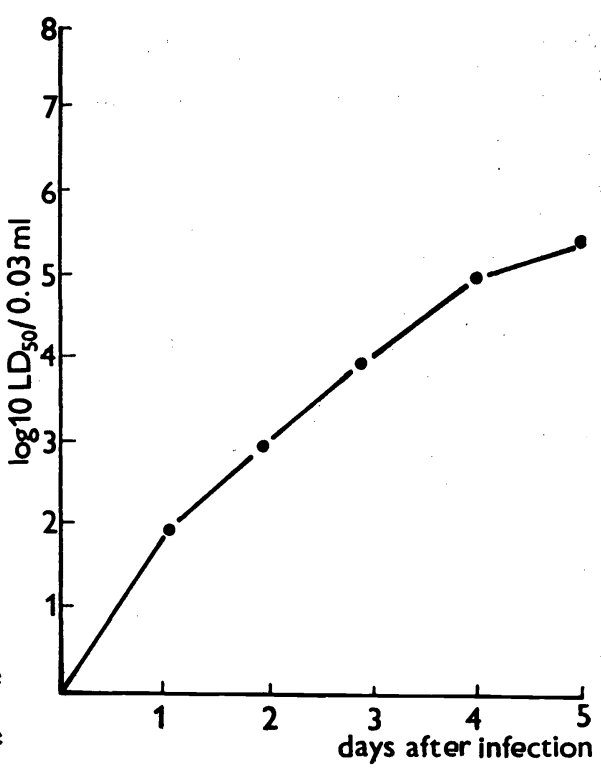

of the virus adaptation. For instance, Rulka and co-workers (1974) reported the highest titre of the virus on day 7 in passage No. 30, and on day 10-11 in passage 20 in their CC. The variations can also result from the infected cell to its neighbours can proceed in way of an extracellular transfer or through intercellular 
bridges, betause not even the presence of an antirabies immune serum could prevent and increase in the number of the infected cells which follows from the experiments of Wiktor and Dietzchold (1977).

\section{Kinetika multiplikace viru vztekliny na buněčné kultư̆e}

Při sledováni kinetiky multiplikace rabického viru $\mathbf{v}$ průběhu jeho adaptace na BK BHK-21 a VERO jsme zjistili pruní specifické inkluze za 6-8 hodin po infekci u $1 \%$ buněk, za 24 hodin pak u $100 \%$ buněk. Maximáln' titr extracelulárního viru v BK byl zjištěn 5 . den ve výši $10^{-7,2} \mathrm{TKID}_{, 0} / 1 \mathrm{~lm}$ titrací na $\mathrm{m}_{y}$ š zích a sklíčkových kulturách.

\section{Кинетика мүльтипликации вируса бешенства на күльтүре тканей}

В ходе исследования кииетики мультипликации вируса бешенства В ходе его приспособления в ВК ВНК-21 и ВЕРО нами были выявлены первые специфические инклюзии через 6-8 часов после инфекции у $1 \%$ клеток, через 1 сутки - у $100 \%$ клетко. Максимальный титр экстрацеллюлярного вируса в ВК был установлен на 5 день на уровне 10-7,2 TKID 1 мл титрования на мышах и предметном стекле.

\section{References}

ABELSETH, M. K.: Propagation of rabies virus in pig kidney cells culture. Can. Vet. J., 5, 1964: 87-92

DEAN, D. J.-ABELSETH, M. K.: Epreuve des anticorps fluorescents. In: Techniques de laboratoire. WHO, Genève, 1974, pp. 75-88

FENJE, P.: Propagation of rabies virus in cultures of hamster kidney cells. Can. J. Mikrobiol., 6, 1960: $479-482$

HRONOVSKÝ, V.-BENDA, R.-CINATL, J.: Propagation of street rabies virus in primary cultures of dog kidney cells. Acta virol., 10, 1966: 181-183

HRONOVSKYY, V.-BENDA, R. - CINÁTL, J.: Process of adaptation of street rabies virus to dog kidney cell primary cultures. Acta virol., 12, 1968: 232-240

KISSLING, R. E.: Growth of rabies virus in non-nervous tissue culture. Proc. Soc. Exp. Biol. Med. 98, 1958: 223-228

REED, L. J. - MUENCH, H.: A simple method of estimating 50 per cent and points. Amer. J. Hyg., 27, 1938: 493-497

RIFKY, M. - EL KARAMANY : Pruduction in VERO cells of an inactivated rabies vaccine from strain FRV/K for animal and human use. Acta virol., 31, 1987:321-328

RULKA, J. - MAJDAN, S. - NIKIEL, J.: Adaptation of Rabies virus (Flury LEP Strain) to Hamster Kidney Cell Culture. Preliminary Report. Acta Microbiol. Polonica, A, 6, 1974: 118 až 122

WIKTOR, T. J.: Dynamics of rabies virus infection in tissue culture. Immunobiological Standardization, 1, 1966: 65-80

WIKTOE, T. J.-DIETZCHOLD, B.-LEAMNSON, R. N.-KOPROWSKI, H.: Induction and biological properties of defective interfering particles of rabies virus. J. Virol., 21, 1977: $626-635$ 
Plate XVII. Celer V. et al.: Kinetics of Rabies...pp. 161-164.

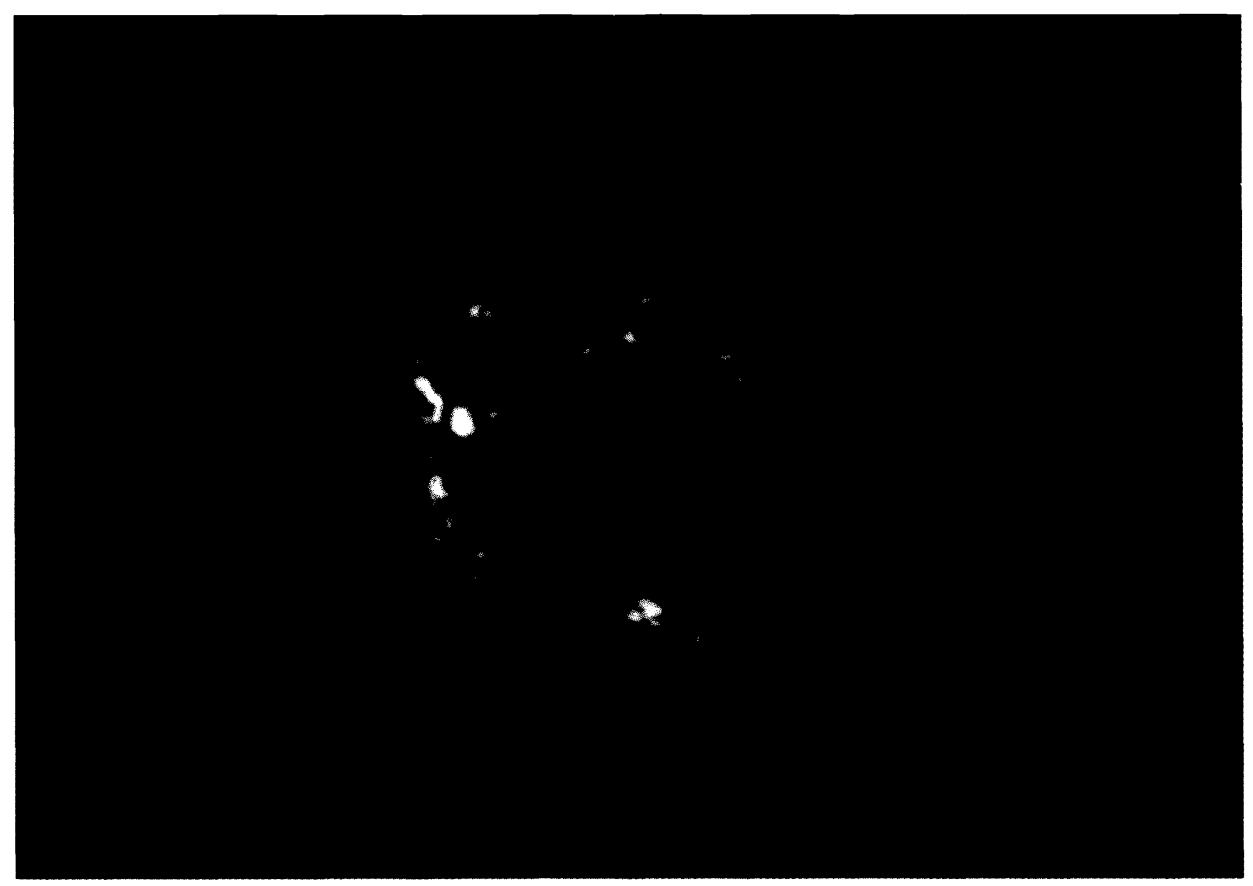

Fig. 1. BHK-21 cell culture 12 hours after infection with lyssa virus showing fluorescing loci.

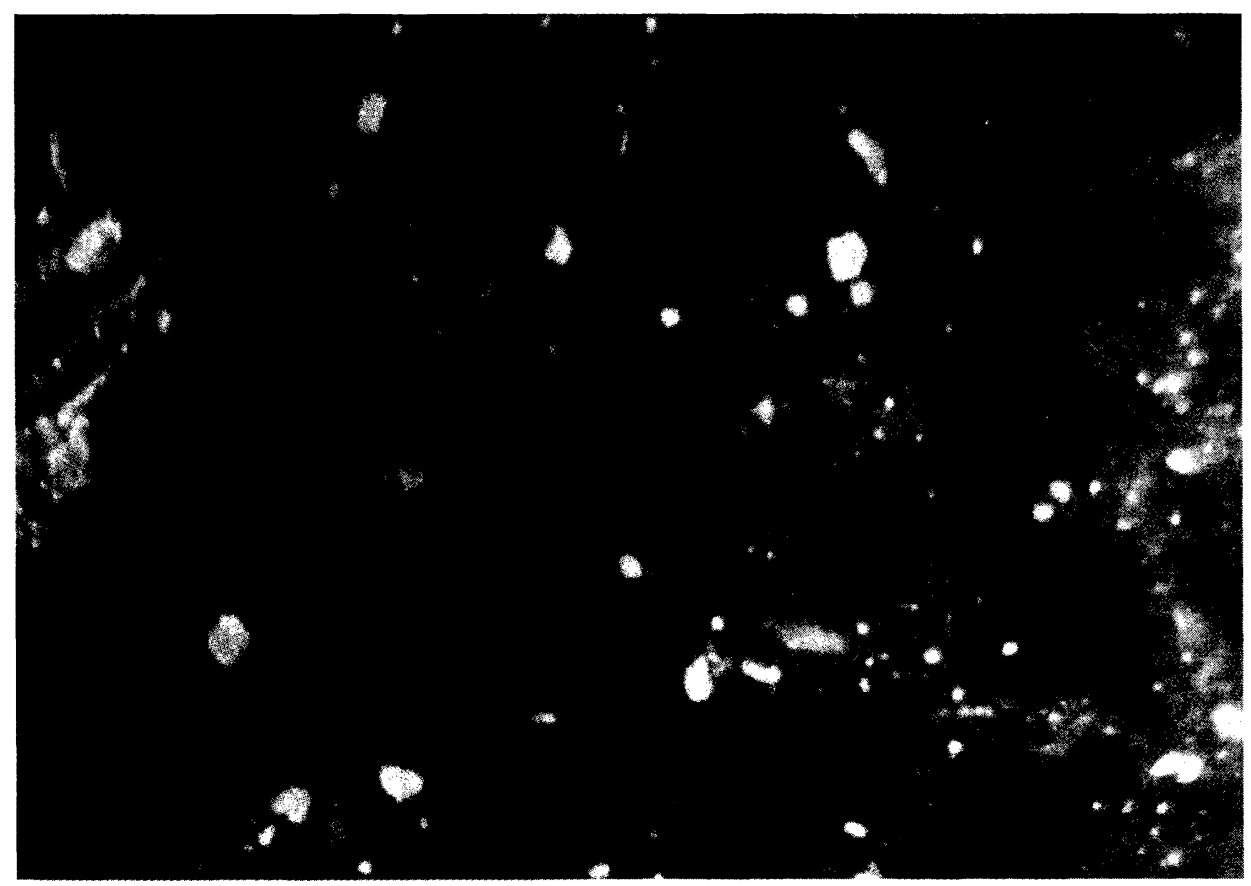

Fig. 2. Fluorescing loci in BHK-21 cell culture 24 hours after lyssa virus infection. 